\title{
Teaching Collegiate Ethics in a Nation with Laws that Permit
}

\section{Mutilation of the Unborn}

\author{
Jill M. Oeding $^{1 *} \&$ Jamie L. Seitz ${ }^{1}$ \\ ${ }^{1}$ Department of Accounting and Finance, University of Southern Indiana, Evansville, Indiana, USA \\ * Jill M. Oeding, E-mail: jmoeding@usi.edu
}

Received: August 2, 2017

doi:10.22158/jepf.v3n3p418
Accepted: August 12, 2017

Online Published: August 25, 2017

URL: http://dx.doi.org/10.22158/jepf.v3n3p418

\begin{abstract}
The devaluing of life through abortion has a detrimental effect on the ethical decision-making processes of a nation of people. Encouraging college students to make ethical decisions in a nation with legalized abortion is challenging. Laws that permit women to have a voluntary abortion are in direct conflict with ethical decision-making. The consequences of decades of abortion in the United States are staggering. Approximately one abortion is performed for every five live births. Over 58,000,000 babies have been aborted in the United States since 1973, when the Supreme Court found that women have the "constitutional right" to have an abortion before "fetal" viability. The authors compared the current abortion law to other "black eyes" in the United States' history including: slavery, the Separate But Equal doctrine, the treatment of Native Americans, and oppressive child labor. This paper then introduces a four-step ethical decision making model and a "toolbox" of questions that students may use when analyzing ethical issues.
\end{abstract}

\section{Keywords}

abortion, ethics, teaching ethics, ethical decision-making, United States

\section{Introduction}

Teaching collegiate ethics in a nation with legalized abortion is a challenge (Note 1). The challenge results from the duty to teach ethical decision-making to college students in a legal environment that permits mutilation of the unborn. The choice to have a voluntary abortion is in direct conflict with ethical decision-making. The authors will use the term "voluntary abortion" to refer to a woman's choice to have an abortion that is not medically necessary to preserve the life of that mother (Note 2).

The lawmakers of the United States should be a good example for their citizens by making laws that forbid abortion, unless the abortion is necessary to preserve the life of the mother. Legalized abortion has led to the murder of millions of innocent, defenseless unborn babies (Note 3). In 1973 the United States Supreme Court decided that women have a "constitutional right" to terminate their pregnancy before 
"fetal" viability (Roe v. Wade). This "constitutional right" encourages a nation of people to disrespect human life and is condoning the murder of unborn babies as a form of birth control. These uncivilized, murderous actions are all defended on the grounds of a woman's right to choice and privacy. Lawmakers in the United States should consider the overall impact of voluntary abortion in the United States and its impact on the culture of the nation.

The issue of abortion should be a moral and ethical issue for the United States rather than a political issue. Bi-partisan games should not have a place in such a substantial issue as the legality of abortion. Lawmakers on both sides of the aisle should have the courage to call voluntary abortion what it is: murder. Voluntary abortion is impacting the culture and values of the people in the United States as it encourages citizens to be irresponsible and selfish with their actions and to disregard the consequence of their sexual activity.

\section{The Consequences of Decades of Legalized Abortion in the U.S.}

The prevalence and consequences of decades of legalized abortion are astounding. Over 58,000,000 abortions have been performed since the Roe v. Wade decision in 1973, according to one website (Ertelt, 2016). The Center for Disease Control and Prevention (CDC) releases an annual Abortion Surveillance Report, which reveals statistics on abortions performed in the United States. The CDC reported that 664,435 legal, induced abortions were reported in 2013 (Abortion surveillance-findings, 2017) (Note 4). In the same year the abortion-to-live-birth ratio was 200 abortions performed per 1,000 live births. Astonishingly, this abortion ratio translates into the performance of one abortion for every five live births.

Forty-four years after the Roe v. Wade decision, Americans are shocked to learn that aborted babies and baby parts are being sold like "goods" on the open market by abortion clinics. Planned Parenthood, a provider of abortion services, was exposed in the media for "selling" baby parts. Undercover journalists posing as employees of a fetal tissue procurement company went to great lengths over the course of years to investigate and expose the practices of Planned Parenthood. In one of ten undercover videos, a Planned Parenthood employee, a Senior Director of Medical Services, stated the clinic would receive "probably anywhere from $\$ 30$ to $\$ 100$ " per specimen (i.e., aborted baby) (Hemmingway, 2015).

In the same video, the Planned Parenthood employee discussed altering the way that abortion is performed based on knowing which organ the tissue procurement company wants. She stated, "We've been very good at getting heart, lung, liver, because we know that, so I'm not gonna crush that part. I'm gonna basically crush below, I'm gonna crush above, and I'm gonna see if I can get it all intact" (Hemmingway, 2015). This conversation is astonishing; it details the methods of destroying a baby to get the most value out of an organ within the baby! One would think that the conversation was regarding goods, not human life.

In another video, the undercover journalist and the Planned Parenthood employee seemed to be "negotiating" or "haggling" over the price of an aborted baby. The undercover journalist asked, "What 
would you expect for intact tissue?" The Planned Parenthood employee then responded, "Well, why don't you start by telling me what you're used to paying?" (Hemmingway, 2015). How much longer will it take for lawmakers to recognize the devastating effects of abortion on the United States and its citizens? This negotiation over baby parts is just one of the consequences of decades of legalized abortion. Hopefully millions of more babies in the United States will not have to lose their lives before voluntary abortion is outlawed.

Gianna Jessen, a survival of a late-term saline abortion in 1977, advocates for the rights of unborn babies. Jessen testified to the House Judiciary Committee and described the method of abortion used on her as "burn[ing] the baby inside and out, blinding and suffocating the child, who is then born dead, usually within 24 hours" (Roys, 2015). Jessen survived the horrific procedure and is now a pro-life advocate. Jessen asked the House Judiciary Committee, "If abortion is about women's rights, then what were mine" (Roys, 2015)? Millions of aborted babies in the last several decades would have become millions of people if the law would have protected them.

In the future, once voluntary abortion is rightfully viewed as a crime, many citizens will look back on the current abortion laws and ask, "How could we let this happen?" The millions of abortions performed over the decades will likely be viewed in history books as the largest genocide in the United States.

\section{Abortion is a "Black Eye" for the United States: Unborn Babies are Treated as an Inferior Class}

Abortion is not the first institution in the United States that was unethical and immoral. Legalized abortion is a "black eye" for the United States, and it is worse than other less-than-honorable legalized doctrines in the nation's past including: slavery, the Separate But Equal Doctrine, the treatment of Native Americans, and oppressive child labor. These groups of people were treated as inferior to other people within the nation.

\subsection{Slavery in the United States}

Slavery was condoned in the United States for hundreds of years until courageous people fought for the rights of African-Americans. Slavery began in the United States in 1619 in Jamestown, Virginia (African Americans at Jamestown, 2015). Slavery continued for almost 250 years until 1865, when Congress ratified the Thirteenth Amendment which officially abolished slavery (13th Amendment, 2015). People in the United States took over two centuries to conclude that slavery was intolerable. African-Americans were treated horrifically for centuries because some self-righteous people considered African-Americans to be "inferior" to other human beings; unborn babies are receiving the same treatment now because some people consider the unborn life to be inferior and worthless.

Something Americans can learn from over two hundred years of slavery is that just because something may be legal does not make the action ethical or moral. Today the rights of unborn babies at all stages of pregnancy should be protected. Similar to the way owning slaves became a way of life for plantation owners in the southern states of the United States, abortion is accepted as a way of dealing with unwanted pregnancies. Abortion has become a way of life and a means of birth control for some people in the 
United States despite its grisly consequences to, what is perceived by some as, an inferior life within the womb.

\subsection{The Separate But Equal Doctrine}

The Separate But Equal Doctrine was another horrific practice in the history of the United States. African-American slaves were given freedom through the Thirteenth Amendment to the Constitution, but many citizens and governments still treated them as inferior through the Separate But Equal Doctrine. The doctrine was intended to afford the races equal treatment by providing "substantially equal facilities, even though the facilities be separate" (Brown v. Board of Education, 1954, p. 488). However, the facilities for white and African-American populations were not equal.

The nation had to live through the consequences of the Separate But Equal Doctrine for decades in order to fully understand the devastating consequences on the country and its citizens. Over fifty years after the Plessy v. Ferguson decision, which upheld the Separate But Equal Doctrine, a unanimous Supreme Court in Brown v. Board of Education overturned the Separate But Equal Doctrine in the context of African-American minors seeking admission to public schools in their community on a non-segregated basis (1954, p. 487). African-Americans were denied admission to schools populated by white children on the basis of laws requiring or permitting the segregation of races. In making its decision, the Court looked at the "effect of segregation itself on public education", considering "public education in the light of its full development and its present place in American life throughout the Nation" (Brown v. Board of Education, 1954, pp. 492-493).

The Court stated that separating children of "similar age and qualification solely because of their race generated a feeling of inferiority as to their status in the community that may affect their hearts and minds in a way unlikely ever to be undone" (Brown v. Board of Education, 1954, p. 494). The Court found that the segregation of children by race in public schools had a "detrimental effect" on African-American children. The Court found the "detrimental effect" of the segregation upon African-American children to be "greater when it has the sanction of the law". The Supreme Court struck down the Separate But Equal Doctrine in the field of public education, holding that the doctrine deprived the plaintiffs of Equal Protection of the law under the Fourteenth Amendment.

Abortion affects the aborted baby's mother, father, and other stakeholders "in a way unlikely ever to be undone". Lawmakers should also consider abortion in light of its current development and place in the lives of American people. The Supreme Court found the "detrimental effect" of segregation upon African-American children to be "greater when [segregation] has the sanction of the law" (Brown v. Board of Education, 1954, p. 494). Likewise, the detrimental effect of abortion in the United States is greater because the barbaric act of abortion has the approval of law.

Legalized abortion is arguably worse than the Separate But Equal Doctrine. The Separate But Equal Doctrine made a population feel inferior; abortion not only makes a class of people (i.e., the unborn) feel inferior, but also physically mutilates and murders the class of people. The mutilation of millions of babies in the last several decades cannot be undone for those lives, but future lives deserve the protection 
of the Equal Protection Clause of the Fourteenth Amendment in addition to the Due Processes Clauses of the Fifth and Fourteenth Amendments, which state that people shall not be deprived of "life, liberty, or property, without due process of law" (Constitution of the United States, 2017). Each unborn baby is a life that should be protected.

\subsection{Treatment of the Native Americans}

Yet another historical example of the United States treating a group of people as inferior is the treatment of Native Americans. The Indian Removal Act of 1830 granted President Andrew Jackson the power to move Indian Tribes that were within state borders and force them to move to unsettled lands west of the Mississippi River (Indian Removal Act, 2017). This action showed no respect or dignity to another class of people, Native Americans, and forced them to leave their homes. Native Americans were treated as though they were inferior to other people in the United States. The United States government treated Native Americans as uncivilized humans when, in reality, the conduct of the U.S. was uncivilized. When some of the tribes refused to move, the U.S. government ordered the U.S. Army to drive them like they were cattle into the designated territory. This journey has been commonly called the Trail of Tears, where thousands of Native Americans died on the over 800 mile journey to the Oklahoma Territory (Indian removal timeline, n.d.).

Native Americans were continually treated like an inferior class of people by moving them out of the way of the country's progress. Not only did the government relocate Native Americans, but the government continued to displace them and did not uphold agreements. The Indian Removal Act was not repealed until March 1980, which was more than 150 years after it was enacted.

\subsection{Child Labor in the United States}

The treatment of children in unsafe working conditions in the United States is another example of disrespect to human life. Children, as young as age seven, worked up to eighteen hours per day preventing them from attending school. In addition, the children were forced to work for wages that were not equal to adults. The use of child labor started when the country began industrializing. Factory owners preferred children because they were more "manageable, cheaper, and less likely to strike" (Child labor, n.d.). The country's progress was more important than the well-being of children. The Fair Labor Standards Act of 1938 finally established federal standards for child labor, protecting children in the workforce, but it took hundreds of years to get to this point.

Slavery, the Separate But Equal Doctrine, the treatment of Native Americans, and oppressive child labor are all examples of immoral and unethical practices that took lawmakers decades, and even centuries, to outlaw. These practices impacted the culture and values of the nation during the short and long-term. They all share a commonality: treating a class of people as inferior to other people. These immoral and unethical practices are viewed with the luxury of hindsight. Now abortion is a modern-day ethical dilemma. Unborn babies are the inferior class of people in some people's minds. History continues to repeat itself. How long will it take the United States to see the devastating effects of abortion on the country, its citizens, and most importantly, the helpless unborn lives it murders? 


\section{Teaching Ethics in the Collegiate Classroom: Less Theory and More Practicality}

The authors teach business ethics, hoping to impress upon students the importance of ethical decision-making in their personal and professional lives. The authors lay the foundation for a deliberate, thoughtful decision-making model that hopefully students will use for future ethical dilemmas by introducing a four-step decision-making model, which is enumerated as follows:

a) Identify the ethical issue(s);

b) Identify the relevant stakeholders;

c) Identify and carefully evaluate alternative courses of action and the implications/consequences for alternative courses of action; and

d) Make a decision as to which course of action is the best course of action (Ethical decision making rubric, 2016; A framework for ethical, 2015).

First, students should identify the ethical issue(s) they are facing. This generally involves framing the issue in terms of a question. Second, students should identify stakeholders of the decision. Stakeholders are those who are "involved in or affected by a course of action" (Merriam-Webster, n.d.). All relevant stakeholders may not be obvious to the students when students first learn to evaluate ethical dilemmas. The list of stakeholders often evolves into a lengthy list once the students brainstorm the parties who may be affected by an ethical issue.

Third, students should consider consequences for various courses of action. This step involves brainstorming several courses of action which could be taken to address the issue and then considering various potential consequences to each course of action. Decision-makers should consider all feasible courses of action as well as best-case consequences, worst-case consequences, and moderate-case consequences for each course of action.

Fourth, students are encouraged to make a decision as to which course of action would be the wisest course of action to take from an ethical perspective given the prior analysis. Figure 1 applies the four-step model to a person who is pregnant and is contemplating an abortion. Figure 2 demonstrates the third step of the four-step model, which details many potential consequences that could follow from various courses of action. 


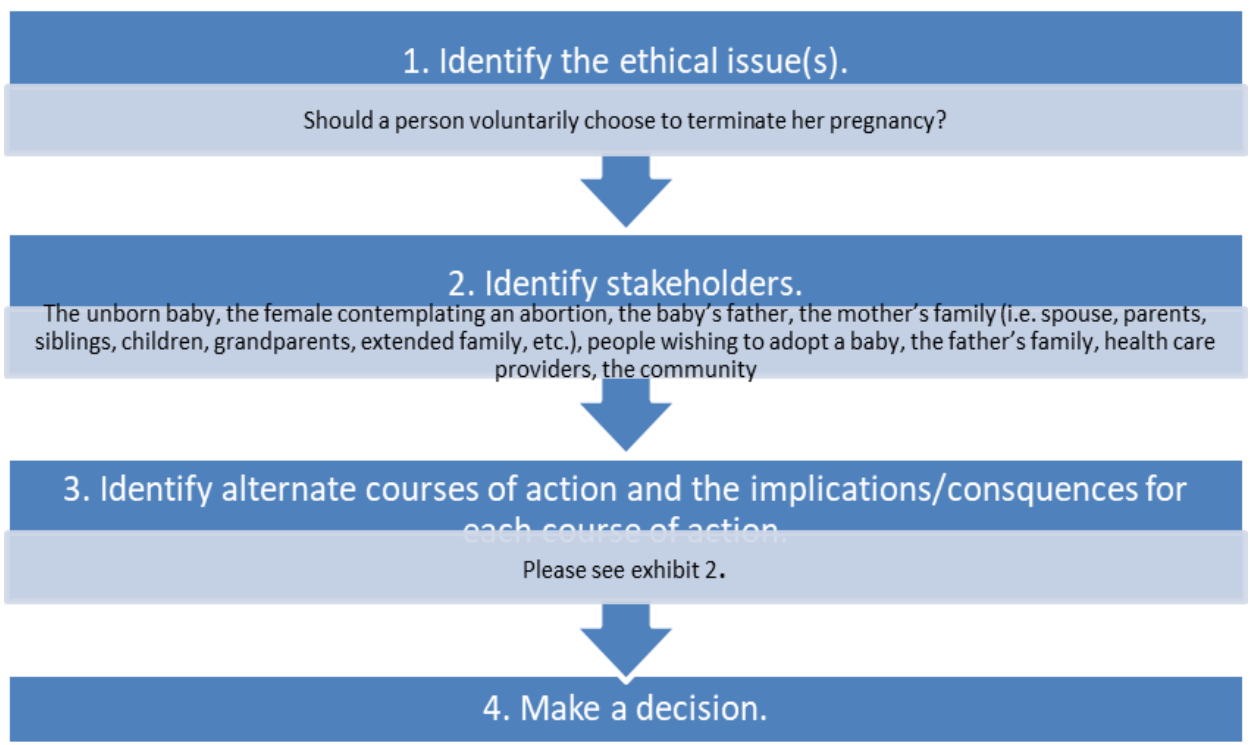

Figure 1. Application of the Four-Step Ethical Decision-Making Model to a Person Contemplating

\section{Abortion}

Alternative Courses of Action

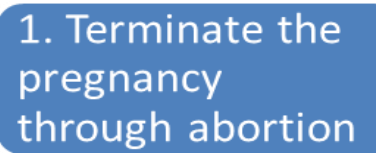

2. Give the baby

up for adoption

\section{Carry the baby \\ to full-term and \\ raise the baby}

\section{Potential Consequences}

- Regret by biological mother and/or other stakeholders

- Emotional, mental, and social injury by one or more

stakeholders

- Medical complications for mother

- Abortion becomes public news

- Relief by one or more stakeholders

- No regret from one or more stakeholders

- No Responsibility to raise a child

- No emotional, mental, or social injury by stakeholder(s)

- 1 Life for the baby

- Relief and joy for adoptive parents

- Baby raised by parents who want the baby

- Sadness and regret by biological family

- Inconvenience of pregnancy

- Expense of pregnancy

- Bilological mother/father may have stigma from pregnancy

\section{- Life for the baby}

- The biological mother and/or father feel at peace with decision

- Financial responsibitity for chid

- Expense of pregnancy

- Biological mother and/or father may not be able to provide for baby

- Biological mother and/or father may not want a baby

Figure 2. Step Three of the Four-Step Ethical Decision-Making Model: Identification of Alternative Courses of Action and Consequences for Each Course of Action for a Person

\section{Contemplating Abortion}

In the midst of applying the four-step model, students should develop a personal "toolbox" of questions to help them thoroughly analyze ethical dilemmas. Professors may help students analyze ethical dilemmas by introducing a "toolbox" of questions that stimulate critical thinking. The following list of questions may help students evaluate the stakeholders and consequences to alternative courses of action:

a) Does the student's action violate the law or company policy (Miller \& Jentz, 2011, p. 55)? 
b) Would the student want their action on the front page of a newspaper or broadcasted in the news media (Miller \& Jentz, 2011, p. 55)?

c) Would the student be likely to regret the action (Zeelenberg, 1999)?

d) Is the student treating someone the way he/she would want to be treated (NIV gift and award Bible, 2011)?

e) Does the student's action complement his/her values and society's values (Miller \& Jentz, 2011, p. $55)$ ?

f) What would the student's hero think of the action he/she is considering (Miller \& Jentz, 2011, p. 55)?

g) Does the action bother the student's conscience (Miller \& Jentz, 2011, p. 55)?

h) What is the worst-case scenario for each course of action?

The authors applied this toolbox of questions to analyze the issue of whether a person should have a voluntary abortion. First, the authors encourage students to determine whether the action they are considering violates the law or company policy (Miller \& Jentz, 2011, p. 55). If the action the student is contemplating is not legal or is against company policy, the students should refrain from the action. Students must also understand that legal conduct is not necessarily synonymous with ethical conduct; a particular action may be legal, but highly unethical.

In the case of abortion, the choice to have a voluntary abortion at certain points during pregnancy is legal. As discussed previously, many less-than-honorable actions (i.e., slavery, the Separate But Equal Doctrine, oppressive child labor, and the poor treatment of Native Americans) were legal at one time in the United States, but the doctrines were not ethical or moral. It took many courageous people to fight to end these institutions. Students should be taught that the ethical inquiry should not end with the legality of an action.

Second, students are prompted to consider whether they would want to have their action published on the front page of the newspaper or broadcasted in the news media (Miller \& Jentz, 2011, p. 55). This is a powerful question and often a show stopper for many students. Many students will recall this particular question when analyzing ethical dilemmas at a later time in the course. In the case of abortion, few women would want the fact that they committed an abortion on the front page of a newspaper or the headline of a news feed. Few women would be proud to admit that they destroyed their own flesh and blood growing within them.

Third, students are challenged to consider any possible regret they might experience in the future due to this decision. Regret is a "negative, cognitively based emotion that we experience when realizing or imagining that our present situation would have been better, had we decided differently" (Zeelenberg, 1999). The possibility of regretting a poor decision in the future is a powerful deterrent for some people (Reb, 2005; Zeelenberg, 1999). Making a poor choice may force the student to regret the decision for the rest of his/her life. Students are encouraged to try to make a wise decision from the beginning rather than living with a lifetime of regret from a particular decision. Applying the issue of regret to abortion, the Supreme Court phrased this well by stating, "[I]t seems unexceptionable to conclude some women come 
to regret their choice to abort the infant life they once created and sustained" (Gonzales v. Carhart, 2006).

Fourth, students apply the Golden Rule to the situation, which states, "[D]o to others what you would have them do to you" (NIV gift and award Bible, 2011). This means that people should treat others the way they would like to be treated. In this step, students should put themselves in the position of other people who may be affected by the decision and should consider how they would like to be treated in a similar situation. Applying the Golden Rule to the question of abortion requires an inquiry into the unborn baby's viewpoint. If the student puts himself/herself in the position of the unborn baby, the question becomes whether the student would want life taken from them. Few people would answer yes. Fifth, the professor asks students to consider whether the decision conflicts with their own values or society's values. Values are “important and lasting beliefs or ideas shared by the members of a culture about what is good or bad and desirable or undesirable. Values have a major influence on a person's behavior and attitude and serve as broad guidelines in all situations" (BusinessDictionary, n.d.). Professors can help students understand the concept of values by asking students what is important to them. Students often come up with answers such as integrity, honesty, fairness, education, and good health. Applying this question to the issue of abortion, Justice Kennedy said that society is shocked when it learns of a "new method of ending human life" (Sternberg v. Carhart, 530 U.S. 914, 2000, p. 957) (Kennedy, J., dissenting). Lawmakers in the United States should consider whether they want current and future generations to devalue human life.

Sixth, students are challenged to contemplate what their "hero" would think about the course of action they may take (Miller \& Jentz, 2011, p. 55). Their hero might be a parent, a grandparent, an aunt, or an uncle. Their hero should be someone who normally makes wise choices from an ethical perspective. Students may even consider talking to their hero about their decision and analyzing the decision. In the case of abortion, if the student's hero is others-centered, the hero would likely discourage abortion, unless the abortion was necessary to save the life of the pregnant mother.

Seventh, students are pointed to their own conscience. If they are feeling guilty about this decision, they should let their "conscience be their guide" (Miller \& Jentz, 2011, p. 55). Students should know that they are facing an ethical dilemma because their conscience alerts them. Many students say that they know they are facing an ethical dilemma when a decision is not easy to make and they spend a longer time thinking about alternative courses of action and the consequences related to them. Professors should encourage students not to ignore this feeling; it is likely their conscience. If students are struggling to make a decision, the decision may have profound consequences for them, the business, and/or other stakeholders.

Eighth, when analyzing each potential course of action, professors should encourage students to consider the worst-case scenario for each potential alternative course of action. What would be considered the worst-case scenario is individual to each person. Prior to taking a particular course of action, a student should be willing to accept and face the worst-case consequence, should that scenario occur. 
Encouraging students to consider the worst-case consequence for course of action will hopefully help students steer clear of the unethical courses of action. For many people the worst-case scenario in the case of abortion is ending a baby's life and regretting the decision for a lifetime.

Students are bombarded with choices each day. These eight questions allow the students to analyze stakeholders, alternative courses of action, and the consequences for each course of action through the lenses of others, society, and their own future viewpoint. Most students tend to gravitate to one to three of these questions and are able to recall them later in the semester. When addressing an ethical issue, students should be encouraged to have integrity to do the right thing, even when no one is looking.

In the case of voluntary abortion, choosing to have an abortion as a form of birth control does not promote "doing the right thing". Rather, abortion is taking the easy way out in the short-term with a decision that the person has to live with in the long-term. Current abortion laws in the United States are diametrically opposed to "doing the right thing". Teaching ethical decision-making in a day and age when the federal laws condone the murder of innocent babies for the sake of convenience screams injustice.

The United States has had many leaders who lead by example by doing the right thing. John F. Kennedy once said, "[A]sk not what your country can do for you - ask what you can do for your country" (Inaugural address, 1961). President Kennedy encouraged Americans to think not of themselves, but rather to think of others and their country. Self-sacrifice and thinking of others' well-being are ideals upon which the nation was founded. Many forefathers did not think of themselves when they sacrificed their lives for the country and the citizens of the United States. For example, George Washington was not thinking of himself when he spent eight years in the field as the commander of the continental army during the Revolutionary War (George Washington's commission, 2017). This was only one of the many sacrifices he made for our country.

The current abortion laws negatively impact the way people value life and the thought processes regarding life. The legalization of abortion also encourages people to think of themselves rather than the life they created. If voluntary abortion were illegal, some women would be more cautious about becoming pregnant if they are not interested in carrying a baby to term.

\section{Conclusion}

The devaluing of life through abortion has a detrimental effect on the decision making processes of a nation of people. Citizens and lawmakers in the United States should not indorse laws that promote barbaric behavior toward innocent, defenseless unborn babies. The treatment of unborn babies as inferior and worthless is worse than other past legalized doctrines, which negatively impacted the values and culture of the nation. Lawmakers in the United States should lead by example by enacting laws that protect unborn babies to show citizens that ethical and moral behavior is more important than aligning with a particular political party. 


\section{References}

13th Amendment to the Constitution. (2015, November 30). Library of Congress. Retrieved July 18, 2017, from http://www.loc.gov/rr/program/bib/ourdocs/13thamendment.html

A framework for ethical decision making. (2015, August 1). Santa Clara University: Markkula Center for $\begin{array}{lllll}\text { Applied } & \text { Ethics. } & \text { Retrieved } & \text { August }\end{array}$ https://www.scu.edu/ethics/ethics-resources/ethical-decision-making/a-framework-for-ethical-deci sion-making/

Abortion surveillance-findings and report. (2017, January 6). Center for Disease Control and Prevention. Retrieved July 18, 2017, from https:/www.cdc.gov/reproductivehealth/data_stats/abortion.htm

African Americans at Jamestown. (2015, February 26). National Park Service. Retrieved July 18, 2017, from http://www.nps.gov/jame/learn/historyculture/african-americans-at-jamestown.htm

Brown v. Board of Education, 347 U.S. 483. (1954).

CDCs abortion surveillance system FAQs. (2017, January 6). Center for Disease Control and Prevention. Retrieved July 18, 2017, from https://www.cdc.gov/reproductivehealth/data_stats/abortion.htm

Child labor in U.S. history. (n.d.). Child Labor Public Education Project. Retrieved July 18, 2017, from https://www.continuetolearn.uiowa.edu/laborctr/child_labor/about/us_history.html

Constitution of the United States. (2017, June 26). National Archives. Retrieved July 20, 2017, from http://www.archives.gov/exhibits/charters/constitution_transcript.html

Ertelt, S. (2016, January 14). 58,586,256 Abortions in America since Roe vs. Wade in 1973. Retrieved July 18, 2017, from http://www.lifenews.com/2016/01/14/58586256-abortions-in-america-sinceroe-v-wade-in-1973/

Ethical decision making rubric for assessment of AACSB learning goal. (2016). Internal document of the University of Southern Indiana, Evansville, Indiana.

George Washington's commission as commander in chief. (2017, April 25). Library of Congress. Retrieved July 20, 2017, from http://www.loc.gov/rr/program/bib/ourdocs/commission.html

Gonzales v. Carhart, 550 U.S. 124. (2006).

Hemmingway, M. (2015, September 29). A quick and easy guide to the planned parenthood videos. The Federalist. Retrieved July 18, 2017, from http://www.thefederalist.com/2015/09/29/a-quick-andeasy-guide-to-the-planned-parenthood-videos/

Inaugural address. (1961, January 20). John F. Kennedy Presidential Library and Museum. Retrieved July 20, 2017, from http://www.jfklibrary.org/Asset-Viewer/BqXIEM9F4024ntF17SVAjA.aspx

Indian Removal Act. (2017, April 25). Library of Congress. Retrieved July 18, 2017, from http://www.loc.gov/rr/program/bib/ourdocs/Indian.html

Indian removal timeline. (n.d.). Digital History. Retrieved July 18, 2017, from http://www.digitalhistory.uh.edu/active_learning/explorations/indian_removal/removal_timeline.cf m

Miller, R., \& Jentz, G. (2011). Business law today: The essentials (9th ed.). Ohio: Cengage Learning. 
NIV gift and award Bible. (2006). Michigan: Zondervan.

Plessy v. Ferguson, 163 U.S. 537. (1896).

Reb, J. (2005). The role of regret aversion in decision making. Proquest Dissertations Publishing. Proquest Central.

Roe v. Wade, 410 U.S. 113. (1973).

Roys, J. (2015, September 9). Gianna Jessen asks congress "If abortion is about women's rights, then what were mine?". Julie Roys. Retrieved July 18, 2017, from http://www.julieroys.com/gianna-jessen-asks-congress-if-abortion-is-about-womens-rights-then-w hat-were-mine/

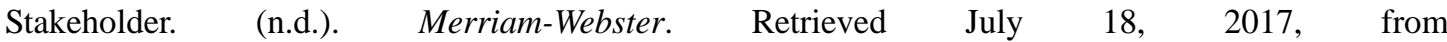
https://www.merriam-webster.com/dictionary/stakeholder

Stenberg v. Carhart, 530 U.S. 914. (2000).

Values. (n.d.) BusinessDictionary. Retrieved July 18, 2017, from http://www.businessdictionary.com/definition/values.html

Zeelenberg, M. (1999). Anticipated regret, expected feedback and behavioral decision making. Journal of Behavioral Decision Making, 12, 93-106. https://doi.org/10.1002/(SICI)1099-0771(199906)12:2\%3C93::AID-BDM311\%3E3.0.CO;2-S

\section{Notes}

Note 1. The information contained in this article is for informational purposes only. It does not constitute legal advice and should not be interpreted as such. Further, this article is based on the views and interpretations of the authors and does not necessarily reflect the views or opinions of entities with which they may be affiliated.

Note 2. If an abortion is necessary to preserve the mother's life, the authors feel the mother has no real choice in the matter.

Note 3. The authors of this paper will refer to the unborn life within a mother's womb as a "baby" as opposed to what some people may refer to as a "fetus". The authors made this choice out of respect for the life within the womb.

Note 4. These numbers regarding abortion are not precise on a national level because states and areas are not legally required to report abortion data to the CDC. Given the lack of reporting requirements, this number is likely low compared to the actual number of abortions performed in the U.S. in that year. 